\title{
A AÇÃO DE AGENTES SOCIAIS NO CAMPO DOS ALEMÃES EM SÃO JOSÉ DOS CAMPOS, SP: GRAFFITI E APROPRIAÇÃO DO ESPAÇO URBANO.
}

\author{
Frederico Papali ${ }^{1}$ \\ Valéria Regina Zanetti ${ }^{2}$ \\ Paula Vilhena Carnevale Vianna ${ }^{3}$
}

Resumo - Este trabalho busca levantar as impressões e repercussões causadas pelo Mutirão Graffiti, $3^{\circ}$ Encontro Internacional de Graffiti ocorrido no bairro Campo dos Alemães, zona Sul da cidade de São José dos Campos em março de 2013. Entendido como um movimento social contemporâneo, pretende-se compreender como as pessoas que pertencem ao lugar o perceberam, enquanto significado e expressão social. O Mutirão reuniu quase três centenas de artistas do Brasil e do exterior e se deu em doze ruas do bairro, que serviram de pano de fundo das obras para a promoção da cultura Hip Hop, tendo o Rap, o graffiti e o break como principais manifestações. Esse estudo se baseou nas concepções teóricas de apropriação do espaço, território e lugar e na análise fotográfica do material produzido pelo mutirão, acessado pelo Google Street View e pelos muros do referido bairro, bem como se valeu de entrevista com um dos artistas que organizou e produziu o evento.

Palavras-chave: Graffiti; Movimentos sociais contemporâneos; Apropriação do espaço; Território; Planejamento Urbano.

\footnotetext{
1 Univap/ IP\&D, Brasil. E-mail: papali@uol.com.br.

2 Univap/IP\&D, Brasil. E-mail: vzanetti@univap.br.

${ }^{3}$ Univap/ IP\&D, Brasil. E-mail: paulavianna@univap.br.
} 